\title{
Effectiveness of Aquatic Therapy on Reducing Pain and Increasing Physical Function in Adult Patients with Hip and/or Knee Osteoarthritis
}

\author{
Hassan Izzeddin Sarsak* \\ Department of Occupational Therapy, School of Rehabilitation Sciences, University of Jordan, Jordan
}

*Corresponding author: Hassan Izzeddin Sarsak, Department of Occupational Therapy, University of Jordan, Jordan, Batterjee Medical College, Saudi Arabia

Submission: 非 October 09, 2018; Published: 監 October 17, 2018

\begin{abstract}
Objectives: this study was conducted to examine the evidence of the effectiveness of aquatic therapy in patients with hip and/or knee Osteoarthritis $(\mathrm{OA})$ on reducing pain and improving physical function.

Results: our review found three studies suggesting that in patients with hip and/or knee OA, the aquatic therapy can reduce pain and improve physical function. OA.

Conclusion: aquatic therapy exercises are effective and helpful in reducing pain and improving physical function in patients with hip and/or knee
\end{abstract}

Keywords: Aquatic therapy; Osteoarthritis; Function; Activities of daily living; Occupational therapy

\section{Introduction}

Osteoarthritis $(\mathrm{OA})$ is the most common type of arthritis with knee being the most affected joint. Most common symptoms of $\mathrm{OA}$ are pain, reduced balance, muscle weakness, decreased Range of Motion, and joint instability Beissner et al. [1]. All these affect performances of activities of daily living (ADL) Kwon et al. [2]. There are many ways to treat OA Lin et al. [3]. One of the methods is aquatic therapy. The beneficial effect of aquatic therapy is reduction of pain by using warm water, buoyancy of water, turbulence or depth of immersion, and facilitating closed-chain exercises Lund et al. [4]. However, there are limitations to this method, which are high cost for setting and lack of studies in community-based settings in OA. The purpose of this study was to examine the evidence of the effectiveness of aquatic therapy in patients with hip and/or knee $\mathrm{OA}$ on reducing pain and improving physical function. For this study, we created a clinical/research PICO question (Population, Intervention, Comparison, and Outcome), a key to evidence-based decision Richardson et al. [5]. The PICO formed for our study is as follows:
P: For patients with hip and/or knee OA
I: Does aquatic therapy
C: Compared to other therapy or control conditions
O: Reduce pain and/or increase physical function?

\section{Methods}

Review of literature and search strategy: A research has been made in the following databases: Ovid, MEDLINE, Global Health, and CINAHL. Keywords and Search items used to search articles for our study were Aquatic therapy, Osteoarthritis, function, activities of daily living, occupational therapy. We used PICO method to search for the relevant articles that have the evidence. We then selected the strongest study based on a variety of factors, such as relevance, study design, sample size, outcomes, significance, year of publication, and intensity of the intervention (frequency and duration).

\section{Results}

Our review revealed three articles that focus most relevantly on the purpose of this study. Evidence study design and study level were determined based on the hierarchy of levels of evidence in evidence-based practice Hughes [6]. The first study Wang et al. [7] was level II evidence with a randomized controlled trial design. The participants were 38 subjects with OA of hip and/or knee. Also, they were directed to do 50 minutes aquatic exercise, 3 random days per week for 12 weeks. The exercise was composed of warm up, flexibility, strength training, and cool down. The temperature of pool was about 30 degree Celsius. The results were significant improvements on 3 out of 4 physical functions measurement and no 
significant change on pain measurement. The second study Hinman et al. [8] was level II evidence with a single blinded randomized controlled trial design. In this study, the participants were 71 subjects with $\mathrm{OA}$. They were directed to do 45 to 60 minutes of aquatic exercise, twice weekly for 6 weeks. The exercises were functional weight-bearing and progressive exercise. The temperature of pool was 34 degrees. The results were significant improvements on both pain and physical functions. The third study Silva et al. [9] was level II evidence with randomized controlled trial design with blinded investigator. In this study, the participants were 64 subjects with $\mathrm{OA}$ divided into groups of 5 to 8 participants. They were directed to do 50 minutes aquatic training session, 3 times a week for 18 weeks. The exercise composed of static stretching, isometric and isotonic strengthening of major muscle group of the lower extremities, and gait training. All adapted land-based exercises with floaters and increased speed. The pool was 32 degrees. The results were divided into 2 groups which are intergroup and intragroup. The intergroup comparison showed significant improvement on pain.
The intragroup comparison showed significant improvement on pain but not as much improvement on physical functions.

\section{Discussion}

We chose the strongest study by considering different factors, such as year of publication, intensity of intervention, and detailed explanation of intervention. Silva study had the most recent publication year. Also, its experiment had the longest duration. Furthermore, it had the most detailed explanation of treatment plan. Therefore, Silva study was selected as the strongest evidence in our review and showed that aquatic therapy reduces pain in OA condition and leads to improvements in physical function. So, depending on Silva et al. [9], we created clinical guidelines and recommendations to follow aquatic therapy protocol in clinics. Our study protocol can be applied in case of all individuals with $\mathrm{OA}$ of hip and/or knee joint. Thus, clinical guidelines, recommendations, a plan and audit tool have been developed in our study to implement aquatic therapy in clinical settings (Table 1 ).

Table 1: A summary of recommendations, plan, and audit tool.

\begin{tabular}{|c|c|c|c|c|}
\hline Recommendation & Implementation Plan & Criteria & Audit Method & Compliance Plan \\
\hline $\begin{array}{l}\text { 1. Physicians will be } \\
\text { given a summary of the } \\
\text { supporting article and } \\
\text { an intervention plan. } \\
\text { Or small seminar can be } \\
\text { arranged for physicians } \\
\text { explaining the new treat- } \\
\text { ment protocol for osteo- } \\
\text { arthritis and the evidence } \\
\text { behind this. }\end{array}$ & $\begin{array}{l}\text { An occupational therapy (OT) } \\
\text { manager will provide each } \\
\text { physician a summary of the } \\
\text { supporting article and an in- } \\
\text { tervention plan. The physicians } \\
\text { will be asked to give c } \\
\text { with their signature. }\end{array}$ & $\begin{array}{l}\text { All physicians who re- } \\
\text { ceive a summary or } \\
\text { attend seminar of the } \\
\text { supporting article and } \\
\text { an intervention plan } \\
\text { will return comments } \\
\text { on the intervention } \\
\text { plan with their signa- } \\
\text { ture }\end{array}$ & $\begin{array}{l}\text { The OT manager will keep } \\
\text { a list of the physicians who } \\
\text { received a summary of the } \\
\text { supporting article and an } \\
\text { intervention plan or who at- } \\
\text { tended seminar on the topic } \\
\text { in the ring binder. Then, the } \\
\text { OT manager will track physi- } \\
\text { cians who return comments } \\
\text { and do not return comments. }\end{array}$ & $\begin{array}{l}\text { The OT manager will remind } \\
\text { physicians who do not return the } \\
\text { comments or signature within } 2 \\
\text { weeks. If a new physician is em- } \\
\text { ployed, the OT manager will send } \\
\text { a summary of the supporting arti- } \\
\text { cle and an intervention plan. Also, } \\
\text { the OT manager will request that } \\
\text { the physicians return comments } \\
\text { with their signature within } 2 \\
\text { weeks. }\end{array}$ \\
\hline $\begin{array}{l}\text { 2. An interested qualified } \\
\text { therapist will attend a } \\
\text { training course in aquatic } \\
\text { therapy. }\end{array}$ & $\begin{array}{l}\text { The Department of OT will en- } \\
\text { roll the therapist in a training } \\
\text { course in aquatic therapy. }\end{array}$ & $\begin{array}{l}\text { The therapist who at- } \\
\text { tended the training } \\
\text { course will obtain a } \\
\text { certificate as proof of } \\
\text { competency in aquatic } \\
\text { therapy. }\end{array}$ & $\begin{array}{l}\text { The OT manager will check } \\
\text { the certificate and keep the } \\
\text { certificate in the ring bind- } \\
\text { er. Every } 2 \text { months, the OT } \\
\text { manager will also confirm } \\
\text { the presence of a certified } \\
\text { therapist. }\end{array}$ & $\begin{array}{l}\text { If the therapist fails to obtain } \\
\text { the certification (therapist will } \\
\text { not be appointed on program as } \\
\text { instructor if he/ she cannot pro- } \\
\text { duce certification) or the certified } \\
\text { therapist is transferred to anoth- } \\
\text { er institute, a new therapist will } \\
\text { attend a training course in aquat- } \\
\text { ic therapy to obtain a certificate. }\end{array}$ \\
\hline $\begin{array}{l}\text { 3. Therapists will show } \\
\text { competency in use of all } \\
\text { of the following outcome } \\
\text { measures: Lequesne In- } \\
\text { dex for OA, WOMAC, Pain } \\
\text { on } 100 \text {-mm VAS before } \\
\text { and after 50FWT, walking } \\
\text { time at fast and comfort- } \\
\text { able paces during 50FWT, } \\
\text { and number of NSAIDs. }\end{array}$ & $\begin{array}{l}\text { Therapist should obtain certifi- } \\
\text { cation of all the outcome mea- } \\
\text { sures to be used in the study, } \\
\text { Maximum three attempts will } \\
\text { be provided to pass the test } \\
\text { and achieve certification of } \\
\text { competency. The noncertified } \\
\text { therapists will take the tests } \\
\text { before being qualified as train- } \\
\text { ers for the aquatic program. }\end{array}$ & $\begin{array}{l}\text { Therapists providing } \\
\text { proof of certification } \\
\text { of competency of all } \\
\text { outcome measures will } \\
\text { be qualified to be the } \\
\text { trainers for the pro- } \\
\text { gram. }\end{array}$ & $\begin{array}{l}\text { The OT manager will keep } \\
\text { record of certificates re- } \\
\text { lated to competency in all } \\
\text { outcome measures of all } \\
\text { instructing therapists of the } \\
\text { program. }\end{array}$ & $\begin{array}{l}\text { Therapists who could not meet } \\
\text { the criteria for passing will take } \\
\text { the certification test after } 1 \text { week } \\
\text { with or without reeducation. It } \\
\text { will be mandatory for therapist } \\
\text { to pass the test within } 3 \text { attempts. }\end{array}$ \\
\hline
\end{tabular}




\begin{tabular}{|c|c|c|c|c|}
\hline $\begin{array}{l}\text { 4. Therapists will deter- } \\
\text { mine the appropriate } \\
\text { patients considering the } \\
\text { inclusion and exclusion } \\
\text { criteria in the evidence } \\
\text { article. }\end{array}$ & $\begin{array}{l}\text { Instructor therapists who } \\
\text { showed competency in evalua- } \\
\text { tion of outcome measures, and } \\
\text { carrying out aquatic therapy } \\
\text { program will determine which } \\
\text { patients best fit the recom- } \\
\text { mended intervention accord- } \\
\text { ing to the study. }\end{array}$ & $\begin{array}{l}\text { OT manager will make } \\
\text { sure that all of the pa- } \\
\text { tients chosen will meet } \\
\text { the inclusion and exclu- } \\
\text { sion criteria in the evi- } \\
\text { dence study. }\end{array}$ & $\begin{array}{l}\text { The OT manager will check } \\
\text { the eligibility of chosen pa- } \\
\text { tients once a month. Also, } \\
\text { the OT manager will main- } \\
\text { tain record of the specific } \\
\text { medical conditions of the } \\
\text { chosen patients and keep } \\
\text { them for further reference. }\end{array}$ & $\begin{array}{l}\text { The OT manager will remind } \\
\text { those therapists who fail to } \\
\text { choose appropriate patients } \\
\text { according to the inclusion and } \\
\text { exclusion criteria. They will be } \\
\text { asked to put a copy of the crite- } \\
\text { ria on their desk, or appear for } \\
\text { an exam set by manager testing } \\
\text { knowledge of criteria required for } \\
\text { the program. }\end{array}$ \\
\hline $\begin{array}{l}\text { 5. Therapists will provide } \\
\text { brochures explaining in- } \\
\text { tervention protocol and } \\
\text { its effects on OA to select- } \\
\text { ed participants. }\end{array}$ & $\begin{array}{l}\text { In the first therapist- patient } \\
\text { meeting after confirming pa- } \\
\text { tient for aquatic therapy, each } \\
\text { therapist will provide partic- } \\
\text { ipants with informative bro- } \\
\text { chure to clear their concepts } \\
\text { about the study. }\end{array}$ & $\begin{array}{l}\text { Therapists will make } \\
\text { a correct informative } \\
\text { brochure or handout of } \\
\text { aquatic therapy. Ther- } \\
\text { apists will provide all } \\
\text { standard information. } \\
\text { Each therapist will col- } \\
\text { lect signature and com- } \\
\text { ments from each sub- } \\
\text { ject at the same time. }\end{array}$ & $\begin{array}{l}\text { The manager will get feed- } \\
\text { back from patients if they } \\
\text { received and understood all } \\
\text { information and materials } \\
\text { within } 1 \text { week from the first } \\
\text { patient-therapist interac- } \\
\text { tion. }\end{array}$ & $\begin{array}{l}\text { The OT manager will examine } \\
\text { handouts to be distributed among } \\
\text { the patients for correct and de- } \\
\text { tailed information before they are } \\
\text { distributed. }\end{array}$ \\
\hline $\begin{array}{l}\text { 6. Therapists will evaluate } \\
\text { the eligible patients with } \\
\text { outcome measures for } \\
\text { baseline data. }\end{array}$ & $\begin{array}{l}\text { Therapists selected as instruc- } \\
\text { tors for training aquatic thera- } \\
\text { py program will collect data on } \\
\text { all outcome measures at base- } \\
\text { line in case of eligible subjects } \\
\text { of the study. }\end{array}$ & $\begin{array}{l}\text { All of the eligible pa- } \\
\text { tients will be evaluat- } \\
\text { ed in an appropriate } \\
\text { manner before starting } \\
\text { aquatic therapy. }\end{array}$ & $\begin{array}{l}\text { The OT manager will keep } \\
\text { record of the results of the } \\
\text { evaluations for further ref- } \\
\text { erence. }\end{array}$ & $\begin{array}{l}\text { OT manager will educate those } \\
\text { therapists who did not evaluate } \\
\text { patients before beginning with } \\
\text { aquatic therapy or evaluated } \\
\text { them in an incorrect manner. In } \\
\text { such cases, re-evaluation will be } \\
\text { presented to OT manager in } 2 \\
\text { days. If needed, the OT manag- } \\
\text { er can require the therapists to } \\
\text { undergo the education process } \\
\text { again. }\end{array}$ \\
\hline $\begin{array}{l}\text { 7. Therapists will provide } \\
\text { aquatic therapy to the pa- } \\
\text { tients. }\end{array}$ & $\begin{array}{l}\text { Therapists will provide aquat- } \\
\text { ic therapy to the patients. In } \\
120-\mathrm{cm} \text { deep pool maintained } \\
\text { at } 32^{\circ} \mathrm{C} \text {, aquatic therapy will } \\
\text { be given in a group of } 5 \text { to } 8 \\
\text { people. Exercises will include } \\
\text { stretching and strengthening } \\
\text { of the major muscle groups of } \\
\text { the lower extremities, along } \\
\text { with gait training. }\end{array}$ & $\begin{array}{l}\text { Therapist will provide } \\
\text { aquatic therapy follow- } \\
\text { ing the intervention } \\
\text { protocol. }\end{array}$ & $\begin{array}{l}\text { OT manager will check if } \\
\text { the aquatic therapy given } \\
\text { to patients is appropriate } \\
\text { once every week. }\end{array}$ & $\begin{array}{l}\text { Manager will keep check on ap- } \\
\text { propriateness of therapy given } \\
\text { to each patient every week. If any } \\
\text { therapist fails to follow the proto- } \\
\text { col, reeducation of protocol will } \\
\text { be made mandatory. OT manager } \\
\text { will decide if they have to pass the } \\
\text { test set by manager to continue } \\
\text { being instructor for the program. }\end{array}$ \\
\hline $\begin{array}{l}\text { 8. Using the outcome } \\
\text { measures, the therapists } \\
\text { will re-evaluate the pa- } \\
\text { tients at 9th and 18th } \\
\text { weeks of aquatic therapy } \\
\text { intervention. }\end{array}$ & $\begin{array}{l}\text { Instructor therapists will col- } \\
\text { lect data on outcome measures } \\
\text { at } 9 \text { th and } 18 \text { th weeks to keep } \\
\text { follow-up of effects of aquatic } \\
\text { therapy on participants. They } \\
\text { will also notice number and } \\
\text { reasons of dropouts, or ad- } \\
\text { verse effects due to therapy. }\end{array}$ & $\begin{array}{l}\text { All of the patients who } \\
\text { received aquatic thera- } \\
\text { py will be re-evaluated } \\
\text { at } 9 \text { th and } 18 \text { th weeks } \\
\text { in an appropriate man- } \\
\text { ner. }\end{array}$ & $\begin{array}{l}\text { OT manager will check } \\
\text { re-assessments at 9th and } \\
\text { 18th weeks and give ap- } \\
\text { proval for continuation of } \\
\text { aquatic therapy. The results } \\
\text { of the re-evaluations will be } \\
\text { kept in record for further } \\
\text { reference. The OT manager } \\
\text { will check each therapist } \\
\text { once in } 2 \text { weeks to ensure } \\
\text { that he/she is in compli- } \\
\text { ance with the standard in- } \\
\text { tervention. }\end{array}$ & $\begin{array}{l}\text { OT manager will educate those } \\
\text { therapists who did not evaluate } \\
\text { patients at 9th and } 18 \text { th weeks } \\
\text { of aquatic therapy or evaluated } \\
\text { them in an incorrect manner on } \\
\text { the importance of the evalua- } \\
\text { tions. Such therapists might have } \\
\text { to undergo the education process } \\
\text { again, and pass the test set by the } \\
\text { manager. }\end{array}$ \\
\hline
\end{tabular}

\section{Conclusion}

Our review suggests that aquatic therapy exercises are effective and helpful in reducing pain and improving physical function in patients with hip and/or knee OA. Thus, clinical guidelines, recommendations, a plan and audit tool have been created in our study to implement aquatic therapy in clinics. The clinical guidelines for recommended intervention, the plan, and the audit tool recommend therapists to apply aquatic therapy with patients with hip and/or knee OA.

\section{References}

1. Beissner KL, Collins JE, Holmes H (2000) Muscle force and range of motion as predictors of function in older adults. Physical Therapy $80(6)$ : 556-563.

2. Kwon IS, Oldaker S, Schrager M, Talbot LA, Fozard JL, et al. (2001) Relationship between muscle strength and the time taken to complete a standardized walk-turn-walk test. Journal of Gerontology Series A 56(9): B398-B404.

3. Lin SY, Davey RC, Cochrane T (2004) Community rehabilitation for older adults with osteoarthritis of the lower limb: A controlled clinical trial. Clinical Rehabilitation 18(1): 92-101. 
4. Lund H, Weile U, Christensen R, Rostock B, Downey A, et al. (2008) A randomized controlled trial of aquatic and land-based exercise in patients with knee osteoarthritis. Journal of Rehabilitation Medicine 40(2): 137144.

5. Richardson WS, Wilson MC, Nishikawa J, Hayward RS (1995) The wellbuilt clinical question: A key to evidence-based decision. ACP Journal Club 123(3): A12-A13.

6. Hughes I (2006) Action research in healthcare: what is the evidence? ALAR Journal 11(1): 29-39.

7. Wang TJ, Belza B, Thompson FE, Whitney JD, Bennett K (2007) Effects of aquatic exercise on flexibility, strength and aerobic fitness in adults with osteoarthritis of the hip or knee. Journal of Advanced Nursing 57(2): 141-152.

8. Hinman RS, Heywood SE, Day AR (2007) Aquatic physical therapy for hip and knee osteoarthritis: Results of a single-blind randomized controlled trial. Physical Therapy, 87(1): 32-43.

9. Silva LE, Valim V, Pessanha AC, Oliveira LM, Myamoto S, et al. (2008). Hydrotherapy versus conventional land-based exercise for the management of patients with osteoarthritis of the knee: A randomized clinical trial. Physical Therapy 88(1): 12-21.

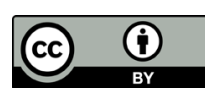

Creative Commons Attribution 4.0 International License

For possible submissions Click Here

\section{Submit Article}

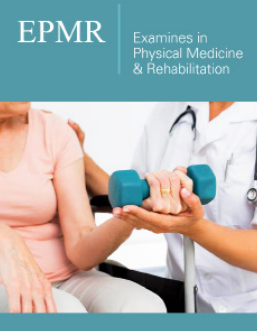

Examines in Physical Medicine and Rehabilitation: Open Access

\section{Benefits of Publishing with us}

- High-level peer review and editorial services

- Freely accessible online immediately upon publication

- Authors retain the copyright to their work

- Licensing it under a Creative Commons license

- Visibility through different online platforms 